DOI: http://dx.doi.org/10.1590/1678-457X.6422

\title{
Molecular screening of bovine raw milk for the presence of Shiga toxin-producing Escherichia coli (STEC) on dairy farms
}

Tatiane VENDRAMIN ${ }^{1}$, Débora Mara KICH${ }^{1}$, Rachel Dias MOLINA ${ }^{1}$, Claucia Fernanda Volken de SOUZA², Rosangela Uhrig SALVATORI ${ }^{1}$, Adriane POZZOBON ${ }^{1}$, Ivan Cunha BUSTAMANTE-FILHO ${ }^{1 *}$

\begin{abstract}
Milkborne transmission of Shiga toxin- producing Escherichia coli (STEC) has raised considerable concern due to recent outbreaks worldwide and poses a threat to public health. The aim of this study was to develop a sensitive and specific multiplex PCR assay to detect the presence of STEC in bovine raw milk. To identify E. coli (ATCC 25922) contamination, the gene uspA was used, and PCR sensitivity and specificity were accessed by testing diluted samples ranging from 2 to $2.0 \times 10^{6} \mathrm{CFU} / \mathrm{mL}$. To detect STEC, the stx 1 and stx 2 genes were selected as targets. After reaction standardization, the multiplex assay was tested in raw milk collected from 101 cows on dairy farms. PCR assay for E. coli detection had a specificity of $100 \%$ and sensitivity of $79 \%(\mathrm{P}<0.0001)$, with a lower detection limit of $2 \mathrm{CFU} / \mathrm{mL}$. Multiplex PCR assay had $100 \%$ sensitivity for E. coli positive raw milk samples, and $31.1 \%$ were contaminated with STEC, $28.3 \%$ of stx2, and $1.9 \%$ of stx 1 . The multiplex PCR assay described in the present study can be employed to identify and screen E. coli harboring stx 1 and stx2 genes in raw milk on dairy farms and in industries.
\end{abstract}

Keywords: shiga-toxin; cattle; multiplex PCR; milk.

\section{Introduction}

Escherichia coli is a Gram-negative, nonsporulating, rod shaped, flagellated, and facultative anaerobic bacteria belonging to the Enterobacteriaceae Family. Based on its virulence, this species is classified as enterotoxigenic E. coli (ETEC), enteropathogenic E. coli (EPEC), enterohemorrhagic E. coli (EHEC), attaching and effacing E. coli (AEEC), and Shiga toxinproducing E. coli (STEC) (Bavaro, 2012).

The Shiga toxin-producing E. coli are an important emerging group of foodborne pathogens. These strains harbor the phage-encoded genes stx 1 and stx2, coding for cytotoxins that cause severe tissue damage, specially STX2 that cause a variety of human illnesses ranging from diarrhea to hemorrhagic colitis (HC), thrombotic thrombocytopenia purpurea (TTP), and hemolytic uremic syndrome (HUS) with fatal consequences (Gyles, 2007; Petruzziello-Pellegrini \& Marsden, 2012; Walker et al., 2012). In Brazil, in a prospective clinical, observational, multicenter, non-controlled and nonrandomized study, conducted between 2001 and 2005, 92.3\% of patients with HUS were infected by STEC. These infected patients' ages ranged from 8 months to 6 years and 3 months, with an average age of 2 years and 5 months. However, almost half of these patients (46\%) were less than 2 years old. These results show a higher risk for pediatric patients, also common victims of foodborne illnesses (Souza et al., 2011).

Ruminants, especially bovines, are the principal reservoir of STEC, and human contamination is often associated with consumption ground beef and direct contact with the animals or their environment (Savoye et al., 2011) STEC strains are highly pathogenic to human in low infectious doses, causing food-borne diseases through consumption of contaminated water or food (Dweik et al., 2012). Bovine milk and other dairy products such as yogurt and cheese have been associated with diseases caused by STEC (Chapman et al., 1993; Prandel et al., 2008; Martin \& Beutin, 2011). Outbreaks of milk-borne diseases associated with STEC, including pasteurized dairy products, have been reported worldwide emphasizing the importance of STEC control for public health (Morgan et al., 1993; Upton \& Coia, 1994; Seghal et al., 2008).

The identification of the presence of microorganisms in the food is the gold standard method to determine food poisoning sources. In most clinical laboratories, identification procedures are based on microbiological culture of milk and biochemical tests of the isolated bacteria. There are disadvantages associated with microbiological culture, such as: a milk culture may yield no bacteria from truly contaminated milk due to the presence of very low numbers of bacteria in the samples, and a negative culture may also be due to the presence of residual therapeutic antibiotics that may inhibit bacterial growth in vitro, more likely, sub lethally-injured or stressed bacteria may not grow directly on selective media, unless allowed to recover on selectively first (Riffon et al., 2001). The detection of STEC strains are labor-intensive, and the total time required for strain characterization is typically $72 \mathrm{~h}$, involving methods such as cytotoxicity assays and Sorbitol MacConkey Agar platting. On the other hand, molecular methods are sensitive, specific, and rapid approaches for detection and characterization of microbiological contaminants in food. 
The development of PCR-based methods for the detection of pathogens or virulence factors (Shahi et al., 2013; Branquinho \& Ferreira, 2012; Gandra et al., 2011) can be used for the initial screening of the presence of microorganisms in samples of milk and dairy products. Furthermore, the present study, through direct isolation of bacterial DNA in milk samples, aimed to develop the multiplex PCR to assess the prevalence of E. coli and STEC in samples of fresh milk.

\section{Materials and methods}

\subsection{Collection of raw milk samples}

This study was carried out on three dairy farms located in Rio Grande do Sul State, Brazil. For the microbiological and molecular biology analyses, $15 \mathrm{~mL}$ of raw milk samples of 101 cows were collected. The milk was drawn by hand directly into sterile test tubes and transported to the laboratory in a cooler containing ice.

\subsection{Microbiological analysis}

To determine contamination of E. coli in milk, Brazilian federal normative (IN62) of the Ministry for Agriculture, Livestock and Supply was followed and used as the standard method (Brasil, 2003). Milk samples were cultured in Violet Red Bile agar (Oxoid Cambridge, UK) at $36^{\circ} \mathrm{C}$ for $24 \mathrm{~h}$. From the samples that tested positive for E. coli, three colonies were transferred to Brilliant Green medium (Acumedia Lansing, USA) and incubated at $36^{\circ} \mathrm{C}$ for $48 \mathrm{~h}$. One loopful of cultures presenting gas production was streaked onto a $\mathrm{EC}$ broth (Acumedia Lansing, USA) and incubated at $36^{\circ} \mathrm{C}$ for $48 \mathrm{~h}$. The samples presenting gas formation were cultured at $36^{\circ} \mathrm{C}$ in Eosin Methylene Blue Agar (EMB, Oxoid Cambridge, UK.). After $24 \mathrm{~h}$, E. coli colonies were counted with standard technique.

\subsection{Preparation of template DNA}

For DNA extraction, $200 \mu \mathrm{L}$ of raw milk sample were used. Briefly, $20 \mu \mathrm{L}$ of Tween- 20 were added to the samples, followed by centrifugation ( $12000 \mathrm{x} \mathrm{g}, 15 \mathrm{~min})$. Pellets were suspended in $60 \mu \mathrm{L}$ extraction buffer ( $100 \mathrm{mM}$ Tris- $\mathrm{HCl}, 100 \mathrm{mM}$ EDTA, $250 \mathrm{mM} \mathrm{NaCl}, \mathrm{pH}$ 8.0) (Invitrogen, Carlsbad, CA, USA), $30 \mu \mathrm{L}$ 10\% SDS (Sigma-Aldrich, St Louis, MO, USA) , $15 \mu \mathrm{L}$ proteinase $\mathrm{K}$ (Ambion ${ }^{\circ}$, Austin, TX, USA) $(20 \mathrm{mg} / \mathrm{mL})$, and $195 \mu \mathrm{L}$ ultrapure water, and they were incubated for $1 \mathrm{~h}$ at $37^{\circ} \mathrm{C}$. Subsequently, $100 \mu \mathrm{L}$ of buffered phenol (ANRESCO, Solon, $\mathrm{OH}, \mathrm{USA}$ ) were added, and the samples were centrifuged (12000 $\mathrm{x} \mathrm{g}, 5 \mathrm{~min}$ ); the supernatant was collected and mixed with 100 $\mu \mathrm{L}$ of phenol-chloroform-isoamyl alcohol (25:24:1) (SigmaAldrich, St Louis, MO, USA) and centrifuged (12000 x g, 5 min). A total volume of $26.5 \mu \mathrm{L}$ of $2 \mathrm{M}$ Sodium acetate (Sigma-Aldrich, St Louis, MO, USA) was added to the supernatant, followed by addition of $400 \mu \mathrm{L}$ of absolute ethanol (Merck, Darmstadt, GER) and overnight incubation at $4^{\circ} \mathrm{C}$. The samples were centrifuged (12000 x g, $20 \mathrm{~min})$ and the pellets with DNA were ressuspended in TE buffer (10 mM Tris-HCL, $1 \mathrm{mM}$ EDTA, $\mathrm{pH} 8,0)$, and stored at $-20^{\circ} \mathrm{C}$ until use. The optical density ratio $(260 / 280 \mathrm{~nm})$ of DNA preparations was considered suitable of downstream applications when greater than 1.6.

\subsection{Molecular characterization of STEC in milk samples}

A multiplex PCR was designed to determine the occurrence of $E$. coli harboring st $x 1$ and/or $s t x 2$ virulence genes in the raw milk samples. Milk DNA samples were used as templates for PCR assays. All primers were from Invitrogen (Carlsbad, CA, USA), and the molecular biology reagents were from Biotools (Madrid, Spain). The names of specific primer sequences, predicted fragment size, and reaction concentrations are presented in Table 1. The uspAgene encoding the universal stress protein was used to detect E. coli DNA (Chen \& Griffiths, 1998). To determine the presence of STEC, primers based on stx1 (Genebank accession number AB083043.1) and stx2 (Genebank accession number AB030484.1) genes were designed for this study. Multiplex PCR conditions were $1.75 \mathrm{mM} \mathrm{MgCl}$, $20 \mathrm{mM}$ Tris- $\mathrm{HCl}, 50 \mathrm{mM} \mathrm{KCL}$ (pH 8.4), $500 \mu \mathrm{M}$ dNTPs, $1.5 \mathrm{U}$ Taq DNA polymerase, and $100 \mathrm{ng}$ of template DNA; $2 \%$ DMSO (Sigma-Aldrich, St Louis, MO, USA) was added to a total volume of $25 \mu \mathrm{L}$. Amplification reactions were carried out using Techne ${ }^{\bullet}$ TC-512 termocycler (Techne ${ }^{\bullet}$ Barloworld Scientific, Stone, Staffordshire, UK) as follows: $5 \mathrm{~min}$ at $94^{\circ} \mathrm{C}, 35$ cycles each consisting of $2 \mathrm{~min}$ at $94^{\circ} \mathrm{C}, 1 \mathrm{~min}$ at $58^{\circ} \mathrm{C}, 1 \mathrm{~min}$ at $72^{\circ} \mathrm{C}$, and a final extension step of $10 \mathrm{~min}$ at $72^{\circ} \mathrm{C}$. Characterization of presence of $E$. coli producer of Shiga I and/or Shiga II toxins were performed by agarose (Invitrogen, Carlsbad, CA, USA), gel electrophoresis stained with ethidium bromide (Sigma-Aldrich, St Louis, MO, USA). E. coli O157:H7 Edl 933 strain (kindly provided by Dr. Caroline de Nardi from Instituto Federal de São Paulo, Brazil) was used as positive control; PCR without template DNA and/or DNA polymerase was performed to be used as negative control.

To determine PCR sensitivity and specificity, sterile whole milk was artificially contaminated with 2 to $2.0 \times 10^{6}$ $\mathrm{CFU} / \mathrm{mL}$ of E. coli (ATCC 25922) culture in stationary phase grown in brain heart infusion (BHI) broth (Sigma-Aldrich, St Louis, MO, USA) for $18-24 \mathrm{~h}$ at $36^{\circ} \mathrm{C}$ (Guido, 2003). The

Table 1. Primer sequences for detection of STEC in raw milk samples.

\begin{tabular}{|c|c|c|c|c|}
\hline Primers & Sequence $\left(5^{\prime}-3^{\prime}\right)$ & Product size & Target gene & Concentration \\
\hline uspAF & CCGATACGCTGCCAATCAGT & \multirow{2}{*}{884 bp } & \multirow{2}{*}{ uspA } & \multirow{2}{*}{$0.5 \mu \mathrm{M}$} \\
\hline uspAR & ACGCAGACCGTAGGCCAGAT & & & \\
\hline stx1F & GATTTATCTGCATCCCCGTACG & \multirow{2}{*}{$346 \mathrm{bp}$} & \multirow{2}{*}{ stx 1} & \multirow{2}{*}{$0.5 \mu \mathrm{M}$} \\
\hline stx1R & CTTACGCTTCAGGCACATACAG & & & \\
\hline stx $2 \mathrm{~F}$ & GGTTAAGCCACTGCCTTTAACTTC & \multirow{2}{*}{$461 \mathrm{bp}$} & \multirow{2}{*}{ stx 2} & \multirow{2}{*}{$1.5 \mu \mathrm{M}$} \\
\hline stx2R & CGGGTGAGTAACGCGTAGGTAA & & & \\
\hline
\end{tabular}


quantification was performed at this stage by plating on the depth of the microorganism suspensions of PCA (Plate Count Agar), followed by incubation at $36^{\circ} \mathrm{C}$ for $48 \mathrm{~h}$. Dilution curves were repeated 8 times, and each point was analyzed in triplicate. DNA extraction and PCR were performed as described above.

\subsection{Statistical analyses}

All statistical analyses were performed using the Prism 5 (Graph Pad Software). The prevalence and frequency of contamination and sensitivity and specificity determination were accessed with exact 95\% confidence interval (CI), KruskalWallis test, Fisher's exact test and Chi-square; $p<0.05$ was considered statistically significant.

\section{Results and discussion}

To validate the use of PCR to detect Escherichia coli contamination in raw milk, the sensitivity and specificity for the primers designed for the uspA gene were checked. The method was compared to microbiological analysis, which showed a total prevalence of contamination of raw milk by $E$. coli of $53.5 \%$ (against to $51.2 \%$ determined by PCR), with no difference $(P=0.3623)$ between the farms evaluated. However, the contamination level on farm $\mathrm{C}(60,508.8 \pm 31,653.8)$ was higher $(\mathrm{P}<0.0001)$ than that on farms $\mathrm{A}$ and $\mathrm{B}, 442.8 \pm 261.27$ and 106.6 \pm 27.3 , respectively (Figure 1).

$100 \%$ specificity and $79 \%$ sensitivity were observed when PCR was performed with DNA obtained from milk artificially contaminated with $2 \mathrm{CFU} / \mathrm{mL}(P<0.0001)$ (Table 2$)$. When PCR was compared to microbiological analysis, $100 \%$ specificity (CI: 0.9328 to 1.000$)$ was observed $(P<0.001)$; however, lower sensitivity (52.48\%; CI: 0.4230 to 0.6251 ) was found. These results may be related to occurrence of samples with

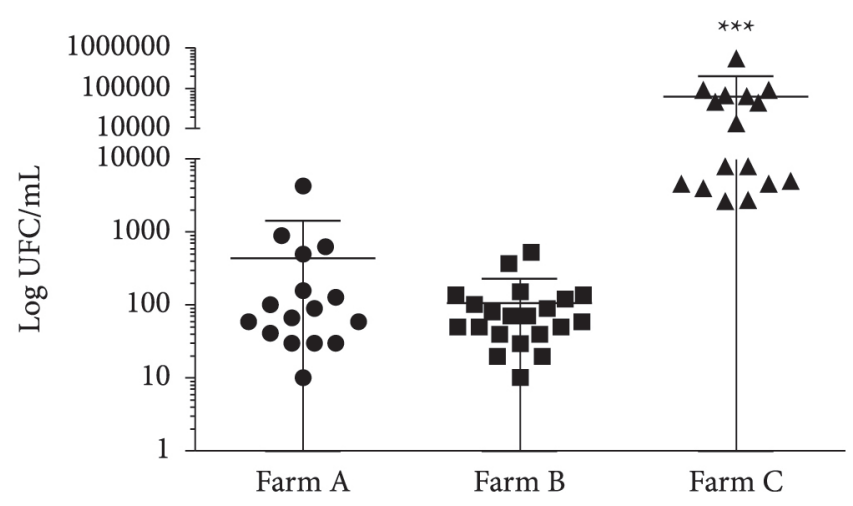

Figure 1. Comparison of milk contamination by E. coli on dairy farms $\mathrm{A}, \mathrm{B}$, and C. Results are presented as Log UFC/mL. Asterisks ( $\left.{ }^{\star * *}\right)$ denote statistical difference $(\mathrm{P}<0.001$, Kruskal-Wallis test). contamination less than $2.0 \times 10^{5} \mathrm{CFU} / \mathrm{mL}$ since the limit for $100 \%$ sensitivity was $2.0 \times 10^{6} \mathrm{CFU} / \mathrm{mL}$.

The molecular characterization of STEC was accessed by means of multiplex PCR. The combination of the three sets of primers allowed the detection of the genes of interest as they produce different sized PCR specific products. Hence, after thorough trials (data not shown), the primer pairs to detect the st $x 1$ and stx 2 genes were found to be highly specific (Figure 2).

The multiplex assay detected that among all E. coli positive samples, $31.1 \%$ were contaminated with STEC. The stx2 fragment was found in 15 samples $(28.3 \%)$, and stx 1 in only one sample (1.9\%), which was not stx 2 positive. Environmental contaminations and poor herd and milking managements are important causes of reduction of milk quality. The high frequency of st 2 in faecal samples collected from buffalo, cows, and goats described elsewhere (Islam et al., 2008; Stephan et al., 2008; Bandyopadhyay et al., 2011, 2012) might explain the prevalence of stx 2 positive STEC in raw milk. In humans, epidemiologic data suggest that E. coli O157 strains that express st 2 are more important than stx 1 in the development of HUS, and that strains that express stx 2 alone are more likely to be associated with the progression to HUS than strains that produce both stx1 and stx2 (Griffin, 1995)

In this study, the presence of STEC harboring the genes st $x 1$ and st $x 2$ in raw milk sample was detected. STEC harboring st $x 1$ and st $x 2$ genes were reported to be typical cattle colonizers (Brett et al., 2003; Vu-Khac \& Cornick, 2008). Some authors have recently investigated 593 foodborne STEC strains for their serotypes and for nine virulence genes (stx 1 , stx $1 c$, st $x 1 d$, st $x 2$, $s t x 2 b$, st $x 2 e, s t x 2 g, E-h l y$ and $e a e)$, and they observed a significant association of stx 1 and stx 2 genes with bovine meat and milk products. These authors compared the properties of foodborne STEC with published data on faecal STEC from food producing animals, and found that virulence profiles and serotypes of STEC from food showed remarkable similarities to those of faecal STEC that were from the same animal species. Based on these results, it has been pointed out that food-producing animals represent the most important source for the entry of STEC in the food chain (Martin \& Beutin, 2011).

It is noteworthy to mention the findings of Kumar et al. (2013), who showed the presence of pathogenic E. coli O157:H7 in pasteurized milk samples. These authors described a higher detection signal after enrichment, suggesting the presence of viable cells after pasteurization or postpasteurization contamination. Therefore, fermented dairy products manufactured using raw milk contaminated with E. coli O157:H7, STEC, or other pathogenic strain can pose a threat to human health, demanding special attention of health and food agencies worldwide. Studies with emphasis

Table 2. Sensitivity and specificity of PCR assay for contamination of raw milk by E. coli. Each concentration was tested in 24 samples.

\begin{tabular}{lccccccc}
\hline \multicolumn{7}{c}{ E. coli concentration in milk samples (CFU/mL) } \\
\hline & $2.0 \times 10^{6}$ & $2.0 \times 10^{5}$ & $2.0 \times 10^{4}$ & $2.0 \times 10^{3}$ & $2.0 \times 10^{2}$ & $2.0 \times 10^{1}$ \\
\hline Sensitivity (\%) & 100 & 83.3 & 95.8 & 83.3 & 95.8 & 83.3 & 79.1 \\
Specificity (\%) & 100 & 100 & 100 & 100 & 100 & 100 & 100 \\
\hline
\end{tabular}

$P<0.0001$ for all values. Fisher Exact test. 


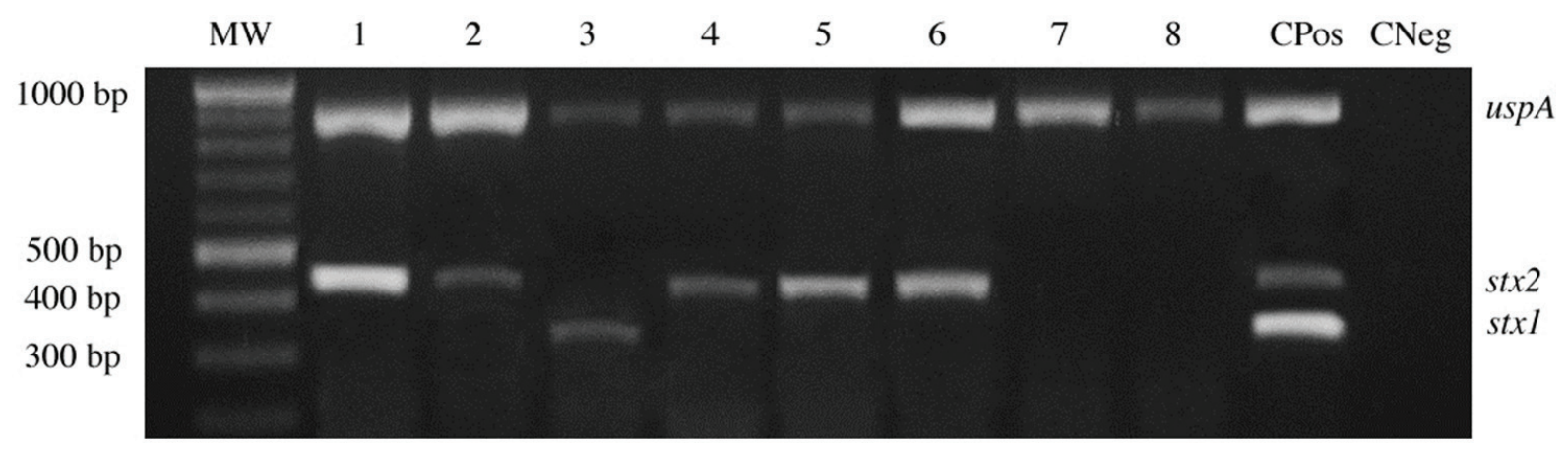

Figure 2. Specificity of multiplex PCR for detection of STEC in raw milk samples. Fragment identifications are presented on the right - uspA (884 bp), stx1 (346 bp) and stx2 (461 bp). Lanes: MW: 100 bp ladder; 1 to 8: milk samples; CPos: positive control (E. coli harboring stx1 and stx2 genes; CNeg: negative control, without template DNA. Agarose gel electrophoresis stained with ethidium bromide.

on detection of pathogens and their virulence factors in food sources may be useful to prevent infection and development of associated diseases.

Our findings on raw milk contamination are meaningful and should be considered since even one Shiga toxin-producing E. coli in a food sample may lead to gastrointestinal or urogenital disorder due to their multiplication in the body or the food itself during storage in poor conditions (Gyles, 2007). Therefore, strict hygiene and management practices for dairy herd and milk processing and storage must be adopted to avoid unwanted illness due contaminated milk and milk products consumption.

\section{Conclusion}

This report presents a quick, sensitive, and specific method for molecular characterization of STEC. In addition, the screening for STEC in three dairy herds showed a significant prevalence of Shiga toxin-producing E. coli contamination in raw milk.

\section{Acknowledgements}

The authors are grateful for the financial support provided by FUVATES.

\section{References}

Bandyopadhyay, S., Lodh C., Rahaman, H., Bhattacharya, D., Bera, A. K., Ahmed, F. A., Mahanti A., Samanta, I., Mondal, D. K., Bandyopadhyay, S., Sarkar, S., Dutta, T. K., Maity, S., Paul, V., Ghosh, M. K., Sarkar, M., \& Baruah K. K. (2012). Characterization of shiga toxin producing (STEC) and enteropathogenic Escherichia coli (EPEC) in raw yak (Poephagusgrunniens) milk and milk products. Research in Veterinary Science, 93(2), 604-610. PMid:22226073. http://dx.doi.org/10.1016/j.rvsc.2011.12.011

Bandyopadhyay, S., Mahanti, A., Samanta, I., Dutta, T. K., Ghosh, M. K., Bera, A. K., Bandyopadhyay, S., \& Bhattacharya, D. (2011). Enterotoxigenic Escherichia coli (ETEC) from diarrhoeic lambs of Arunachal Pradesh, India. Tropical Animal Health and Production, 43(3), 705-710. PMid:21104315. http://dx.doi.org/10.1007/s11250010-9757-1

Bavaro, M. F. (2012). E. coli O157:H7 and other toxigenic strains: the curse of global food distribution. Current Gastroenterology Reports,
14(4), 317-323. PMid:22610457. http://dx.doi.org/10.1007/s11894012-0264-6

Branquinho, M. R., \& Ferreira, R. T. B., \& Cardarelli-Leite, P. (2012). Use of real-time PCR to evaluate two DNA extraction methods from food. Food Science and Technology, 32(1), 112-118.

Brasil. Ministério da Agricultura, Pecuária e Abastecimento. (2003). Oficializa os métodos analíticos oficiais para análises microbiológicas para controle de produtos de origem animal e água (Instrução Normativa $n^{\circ} 62$, de 26 de agosto 2003). Diário Oficial da República Federativa do Brasil.

Brett, K. N., Ramachandran, V., Hornitzky M. A., Bettelheim K. A., Walker M. J., \& Djordjevic S. P. (2003). Stx1c is the most common Shiga toxin 1 subtype among Shiga toxin-producing Escherichia coli isolates from sheep but not among isolates from cattle. Journal of Clinical Microbiology, 41(3), 926-936. PMid:12624011 PMCid:PMC150265. http://dx.doi.org/10.1128/JCM.41.3.926936.2003

Chapman, P. A., Wright, D. J., \& Higgins R. (1993). Untreated milk as source of verotoxigenic Escherichia coli O157:H7. Veterinary Record, 133(7), 171-172. PMid:8236710. http://dx.doi.org/10.1136/ vr.133.7.171

Chen, J., \& Griffiths, M. W. (1998). PCR differentiation of Escherichia coli other Gram negative bacteria using primers derived from the nucleotide sequences flanking the gene encoding the universal stress protein. Letters in Applied Microbiology, 27(6), 369-371. http:// dx.doi.org/10.1046/j.1472-765X.1998.00445.x

Gandra, E. A., Fernandez, M. A., Silva, J. A., \& Silva, W. P. (2011). Standardization of a multiplex PCR for the identification of coagulase-posivite Staphylococcus. Ciência e Tecnologia de Alimentos, 31(4), 946-949. http://dx.doi.org/10.1590/S010120612011000400019

Dweik, M., Stringer, R. C., Dastider, S. G., Wu, Y., Almasri, M., \& Barizuddin, S. (2012). Specific and targeted detection of viable Escherichia coli O157:H7 using a sensitive and reusable impedance biosensor with dose and time response studies. Talanta, 94, 84-89. PMid:22608418. http://dx.doi.org/10.1016/j.talanta.2012.02.056

Guido, M. C. (2003). Detecção de DNA de Brucella abortus pela PCR em leite bubalino experimentalmente contaminado pela amostra 1119-3 (Tese de doutorado). Universidade de São Paulo, São Paulo.

Griffin, P. M. (1995). Escherichia coli O157:H7 and other enterohemorrhagic Escherichia coli. In M. J. Blaser, P. D. Smith, J. I. Rovin, H. B. Greenberg \& R. L. Guerrant (Eds.), Infections of the gastrointestinal tract (pp. 739-761). New York: Raven Press. 
Gyles, C. L. (2007). Shigatoxin-producing Escherichia coli: an overview. Journal of Animal Science, 85(13), 45-62. PMid:17085726. http:// dx.doi.org/10.2527/jas.2006-508

Islam, M. A., Abdus , S. M., Boer, E., Rijkelt, R. B., Marcel, H. Z., Kaisar, A. T., \& Heuvelink, A. E. (2008). Prevalence and genetic characterization of shiga toxin-producing Escherichia coli isolates from slaughtered animals in Bangladesh. Applied and Environmental Microbiology, 74(17), 5414-5421. PMid:18641151 PMCid:PMC2546655. http://dx.doi.org/10.1128/AEM.00854-08

Kumar, A., Grover S., \& Batish V. K. (2013). Application of multiplex PCR assay based on uidR and fliCH7 genes for detection of Escherichia coli O157:H7 in milk. Journal of General and Applied Microbiology, 59(1), 11-19. PMid:23518514. http://dx.doi. org/10.2323/jgam.59.011

Martin, A., \& Beutin, L. (2011). Characteristics of shiga toxinproducing Escherichia coli from meat and milk products of different origins and association with food producing animals as main contamination sources. International Journal of Food Microbiology, 146(1), 99-104. PMid:21371769. http://dx.doi.org/10.1016/j. ijfoodmicro.2011.01.041

Morgan, D., Newman, C. P., Hutchinson, D. N., Walkar, A. M., Rowe, B., \& Majid, F. (1993). Verotoxin producing Escherichia coli O157:H7 infections associated with the consumption of yoghurt. Epidemiology and Infection, 111(2), 181-187. PMid:8405146 PMCid:PMC2271388. http://dx.doi.org/10.1017/S0950268800056880

Petruzziello-Pellegrini, T. N., \& Marsden P. A. (2012). Shiga toxinassociated hemolytic uremic syndrome: advances in pathogenesis and therapeutics. Current Opinion in Nephrology and Hypertension, 21(4), 433-440. PMid:22660553. http://dx.doi.org/10.1097/ MNH.0b013e328354a62e

Prandel, N., Bertin Y., Martin C., \& Livrelli V. (2008). Molecular analysis of shiga toxin-producing Escherichia coli strains isolated from Hemolytic-Uremic Syndrome patients and dairy samples in France. Applied and Environmental Microbiology, 74(7), 2118-2128. PMid:18245246 PMCid:PMC2292610. http://dx.doi.org/10.1128/ AEM.02688-07

Riffon, R., Sayasith, K., Lhalil, H., Dubreuil, P., Drolet, M., \& Lagace, J. (2001). Development of a rapid and sensitive test for identification of major pathogens in bovine mastitis by PCR. Journal of Clinical Microbiology, 39(7), 2584-2589. PMid:11427573 PMCid:PMC88189. http://dx.doi.org/10.1128/JCM.39.7.2584-2589.2001
Savoye, F., Feng, P., Rozand, C., Bouvier, M., Gleizal, A., \& Thevenot, D. (2011). Comparative evaluation of a phage protein ligand assay with real-time PCR and a reference method for the detection of Escherichia coli $\mathrm{O} 157: \mathrm{H} 7$ in raw ground beef and trimmings. Journal of Food Protection, 74(1), 6-12. PMid:21219756. http://dx.doi. org/10.4315/0362-028X.JFP-10-271

Seghal, R., Kumar, Y., \& Kumar, S. (2008). Prevalence and geographical distribution of Escherichia coli O157 in India a 10 year survey. Transactions of the Royal Society of Tropical Medicine and Hygiene, 102(4), 380-383. PMid:18321544. http://dx.doi.org/10.1016/j. trstmh.2008.01.015

Shahi, S. K., Singhm V. K., \& Kumar, A. (2013). Detection of Escherichia coli and associated $\beta$-lactamases genes from diabetic foot ulcers by multiplex PCR and molecular modeling and docking of SHV-1, TEM-1, and OXA-1 $\beta$-lactamases with clindamycin and piperacillin-tazobactam. PLoS One, 8(7), e68234. PMid:23861873 PMCid:PMC3701671. http://dx.doi.org/10.1371/ journal.pone.0068234

Souza, R. L., Carvalhaes J. T. A., Nishimura, L. S., Andrade, M. C., \& Guth B. E. C. (2011). Hemolytic uremic syndrome in pediatric intensive care units in São Paulo, Brazil. Open Microbiology Journal, 5, 76-82. PMid:21804902 PMCid:PMC3143539. http://dx.doi. org/10.2174/1874285801105010076

Stephan, R., Schumacher, S., Corti, S., Krause, G., Danuser, J., \& Beutin, L. (2008). Prevalence and characteristics of shiga toxin-producing Escherichia coli in swiss raw milk cheeses collected at producer level. Journal of Dairy Science, 91(7), 2561-2565. PMid:18565913. http:// dx.doi.org/10.3168/jds.2008-1055

Upton, P., \& Coia, J. E. (1994). Prevalence and geographical distribution of Escherichia coli O157 in India a 10 year survey. Lancet, 344(8928), 1015. http://dx.doi.org/10.1016/S0140-6736(94)91670-5

Vu-Khac, H., \& Cornick, N. A. (2008). Prevalence and genetic profiles of Shiga toxin-producing Escherichia coli strains isolated from buffaloes, cattle, and goats in central. Veterinary Microbiology, 126(4), 356-363. PMid:17716835. http://dx.doi.org/10.1016/j. vetmic.2007.07.023

Walker, C. L., Applegate, J. A., \& Black, R. E. (2012). Haemolyticuraemic syndrome as a sequela of diarrhoeal disease. Journal of Health, Population and Nutrition, 30(3), 257-261. http://dx.doi. org/10.3329/jhpn.v30i3.12288 